\section{Combined effects of silver nanoparticles and humic and fulvic acids on Vibrio splendidus growth}

\author{
K. Doiron, M. Millour, J.-P. Gagné, \\ $K$. Lemarchand
}

Institut des sciences de la mer de Rimouski, Université du Québec à Rimouski, Rimouski, QUE, Canada

\section{Introduction}

Over the last decade, industrial production and commercial use of engineered nanomaterials (ENMs), such as silver nanoparticles (AgNPs) and carbon nanotubes (CNTs), have significantly increased worldwide. Due to their antimicrobial properties, silver nanoparticles (AgNPs) are now extensively used in many consumer-products ${ }^{1}$ like anti-odor textiles and food packaging $^{2}$ as well as in many processes such $\mathrm{as}^{1}$, water purification and production of antifouling and aseptic surfaces. ${ }^{3}$ ENMs can enter aquatic environments from their manufacturing processes to their disposal. As a consequence, the USEPA has included them among the emerging aquatic contaminants since 2009. ${ }^{4}$ Nevertheless, potential toxic effects of these emerging contaminants on natural aquatic communities, from bacterial communities to vertebrates, are still not well understood. ${ }^{5}$ Many studies have described the effects of AgNPs and ionic silver on pathogen microorganism models such as bacterial species of the genus Vibrio, Escherichia and Pseudomonas ${ }^{6-9}$ as well as on complex bacterial communities, ${ }^{10-12}$ but few on environmental bacteria. Moreover, only few environmental studies are taking into account the fact that, in natural aquatic environments, the occurrence of natural organic matter (NOM) could interact with $\mathrm{AgNPs}^{13}$ and, as a consequence, modify their toxicity against aquatic organisms ${ }^{14,15}$ and microorganisms. ${ }^{16}$ These studies have demonstrated that humic acids (HA) and fulvic acids (FA), two important components of the ubiquitous $\mathrm{NOM},{ }^{17}$ could interact with AgNPs..$^{13,18-20}$ The adsorption of FA, HA or NOM onto nanoparticles enhances electrostatic or steric stability. Aggregation of AgNPs could be modified by this new coating at two different levels, at low ionic strength NOM decreases AgNPs aggregation rates, moreover in presence of divalent cation, aggregation processes are promoted by NOM addition. ${ }^{21}$ AgNPs stability influences their toxicity for microorganisms. In estuarine waters, Millour et $a .^{22}$ have recently observed a rapid change in the size of AgNPs influenced by NOM concentration, nevertheless this aggregation was not observed in nanopure water. As a consequence, to better understand the ecotoxicological risk of AgNPs in aquatic environments it is essential to characterize their biocidal (toxicological) effects in association with HA and FA towards bacteria inhabiting these ecosystems. The aim of this study was to determine the toxicity of AgNPs on Vibrio splendidus growth, a wellknown bacterial pathogen, with and without the addition of two NOM components, HA and FA.

\section{Materials and Methods}

\section{Bacterial culture conditions}

Vibrio splendidus $7 \mathrm{SHRW}^{23}$ an environmental strain isolated from the Gulf of St. Lawrence (Quebec, Canada), was grown overnight in LB medium at room temperature. This strain has been previously used in our laboratory and was chosen due to its sensibility to ENMs. ${ }^{24}$ Cultures were centrifuged at $4000 \mathrm{rpm}$ for 5 min. Vibrio cell pellets were washed twice in physiological water $(9 \%$ of $\mathrm{NaCl}, \mathrm{pH} 7.2,0.2$ $\mu \mathrm{m}$ filtered and autoclaved) and finally in nanopure water $(\mathrm{NW}, \mathrm{pH} 7.2,0.2 \mu \mathrm{m}$ filtered and autoclaved) to remove any residual growth medium. Then, Vibrio cell suspensions were diluted in sterile NW to obtain working bacterial suspensions containing $10^{7}$ cell.mL $\mathrm{mL}^{-1}$.

\section{AgNPs, HA and FA exposition conditions}

The different xenobiotics used in this study were AgNPs-citrate $20 \mathrm{~nm}$ (synthesised at E. Pelletier's laboratory-ISMER), Suwannee River humic and fulvic acids standard II (IHSS, St. Paul, MN, USA). At first, the effects of a single exposition of Vibrio cells to AgNPs (0, 20, 100 and $\left.1000 \mu \mathrm{g} . \mathrm{L}^{-1}\right), \mathrm{HA}$ and FA $(0,2.5,10$ and 50 mg. $\left.\mathrm{L}^{-1}\right)$ were assessed. Then, the effects of different combinations of AgNPs/HA and AgNPs/FA, at the same concentrations than previously used during single expositions, were investigated. Bacterial cell expositions to silver nanoparticles were performed in triplicates in nanopure water into $1.5 \mathrm{~mL}$ centrifuge tubes. The nanopure water avoids the risk of agglomeration of AgNPs. Tubes were kept rotating on a shaker incubator at $100 \mathrm{rpm}$ for 2 $\mathrm{h}$ at ambient temperature. After exposition, $100 \mu \mathrm{L}$ of each mix were transferred into 96 well plates containing $100 \mu \mathrm{L}$ of $2 \mathrm{X}$ LB medium. Cell growth was estimated by measuring the optical density (OD) at $595 \mathrm{~nm}$ during $72 \mathrm{~h}$ on a Multiskan Ascent Microplate Photometer (Thermo Scientific). The growth curves were obtained by plotting OD values versus growth time. The specific growth rate $(\mu)$ of each treatment was estimated from the slope regression of $\ln \left(\mathrm{OD}_{595 \mathrm{~nm}}\right)$ versus exponential growth time. ${ }^{25}$
Correspondence: Karine Lemarchand, Institut des sciences de la mer de Rimouski, Université du Québec à Rimouski, 310 Allée des Ursulines, C.P. 3300, Rimouski, Québec, Canada, G5L 3A1. Tel.: + 1.418.723.1986 \#1259

Fax: +1.418.724.1842.

E-mail: karine_lemarchand@uqar.ca

Key words: silver nanoparticles, Vibrio splendidus, humic acids, fulvic acids, growth ability.

Conference presentation: ECOBIM meeting, 2014 May, Brest, France.

Acknowledgments: this work was supported by NSERC strategic grant Tracking silver nanomaterials in the aquatic environment (PI: Émilien Pelletier and Jean-Pierre Gagné) and by FEI-FCI funds (PI: Karine Lemarchand). The authors are grateful to Justine Ginot, Sarah Puloch and Isabelle Desbiens for their technical support.

This work is licensed under a Creative Commons Attribution NonCommercial 3.0 License (CC BYNC 3.0).

CC Copyright K. Doiron et al., 2014

Licensee PAGEPress, Italy

Journal of Xenobiotics 2014; 4:4893

doi:10.4081/xeno.2014.4893

\section{Statistical analyses}

All statistical analyses were done using SYSTAT software version 12.0 (Systat Software Inc., Chicago, USA) with $\alpha=0.05$. Data normality was examined using the KolmogorovSmirnov. Differences between treatments were tested using a 1-way ANOVA. For subsequent multiple comparisons, Tukey's tests was performed when appropriate.

\section{Results and Discussion}

\section{Single exposition to AgNPs, HA or FA}

On a global scale, the growth rate and the lag time required before exponential growth phase of $V$. splendidus cells were significantly affected by a $2 \mathrm{~h}$ exposition to AgNPs at 100 , 500 and $1000 \mu g . \mathrm{L}^{-1}(\mathrm{P}<0.001), \mathrm{HA}$ at 10 and 50 mg. $\mathrm{L}^{-1} \quad(\mathrm{P}<0.001)$ and $\mathrm{FA}$ at $10 \mathrm{mg} . \mathrm{L}^{-1}$ $(\mathrm{P}<0.001)$ (Table 1).

At low concentration (20 $\left.\mu \mathrm{g} . \mathrm{L}^{-1}\right)$, AgNPs did not influence the growth rate of $V$. splendidus cells. At medium concentration (100 $\left.\mu \mathrm{g} . \mathrm{L}^{-1}\right)$, cell growth rate and lag time increased from 9 to $20 \mathrm{~h}(\mathrm{P}<0.001)$ (Table 1). At high AgNPs concentration (1000 $\left.\mu \mathrm{g} . \mathrm{L}^{-1}\right)$, no bacterial growth was observed during the time of the experimentation. Hence the biocidal activity of AgNPs alone is between 100 and $1000 \mu g . \mathrm{L}^{-1}$ (geometric mean of $316 \mu \mathrm{g} . \mathrm{L}^{-1}=$ threshold 
effect). Increasing of the lag time has been already observed on other bacterial strains exposed to AgNPs. ${ }^{3,16}$ The extension of the lag time suggests that bacterial cells were able to adapt to the presence of AgNPs at low-medium concentrations, whereas at higher concentrations, AgNPs are bactericidal for bacterial cells.

The growth rate of $V$. splendidus cells was not affected by addition of HA up to $10 \mathrm{mg} . \mathrm{L}^{-1}$. However, at $50 \mathrm{mg} . \mathrm{L}^{-1}$, HA demonstrated a bactericidal effect (Table 1). During FA expositions, all concentrations significantly decreased the bacterial growth rate and increased the lag time (Table 1). Even if FA effects are concentration-dependant, no bactericidal effect was observed at the highest concentration tested. This result differs from the results obtained during HA expositions. The different toxicity of HA and FA, two components of NOM, toward Vibrio splendidus cells could be related to their structural differences (molecular weight, amount of functional groups, atomic composition ${ }^{20}$ ) which can modify their interactions with the cells. Even if HA effects on biological cells are relatively well documented, ${ }^{18}$ only few information are actually available concerning FA. Moura et al. ${ }^{19}$ have demonstrated the existence of a rapid sorption of HA and FA on Bacillus subtilis cell surfaces. This sorption may affect structure, fluidity and permeability of bacterial cell membranes. ${ }^{26}$ In addition, humic substances could be internalized by bacterial cell ${ }^{27}$ and used as carbon source. ${ }^{18}$ As a consequence, the HA/FA ratio in surface waters could dictate the toxic outcome of AgNPs.

\section{Toxicity of AgNPs/HA and AgNPs/FA combinations}

Single expositions to each xenobiotic (AgNPs, HA and FA) are essential to better understand the specific impacts on bacterial cell growth. Nevertheless, when considering the release of AgNPs in complex natural media, such as aquatic environments, it is essential to consider the effects of xenobiotic interactions on bacterial cells to adequately estimate the ecotoxicological risk of these nanomaterials. Our results clearly demonstrated that combined expositions of bacterial cells to $\mathrm{AgNPs} / \mathrm{HA}$ and to $\mathrm{AgNPs} / \mathrm{FA}$ significantly modified the growth rate of $V$. splendidus (Table 2). No significant difference could be observed in bacterial growth rate when the cells were exposed at $20 \mu \mathrm{g} . \mathrm{L}^{-1} \mathrm{AgNPs}$ whatever the concentrations of HA or FA added in the medium (Table 2). Nevertheless, the lag time increased with increasing NOM concentration (Table 2). At $100 \mu \mathrm{g} . \mathrm{L}^{-1} \mathrm{AgNPs}$, the addition of $10 \mathrm{mg} . \mathrm{L}^{-1} \mathrm{FA}$ (or HA) increased the growth rate and lowered lag time compare to the control without NOM (Table 2), suggesting a reduction of the AgNPs toxicity by HA and FA. Contrary to the results obtained during single

Table 1. Effects of the different concentrations of AgNPs, HA and FA on growth rate and on lag time of the Vibrio splendidus.

\begin{tabular}{lcc} 
Treatments & Growth rate $\left(h^{-1}\right)$ & Lag time $(\mathbf{h})$ \\
Control & $0.13 \pm 0.00$ & 9 \\
AgNPs $20 \mu \mathrm{g} . \mathrm{L}^{-1}$ & $0.13 \pm 0.00$ & 11 \\
\hline AgNPs $100 \mu \mathrm{g} . \mathrm{L}^{-1}$ & $0.18 \pm 0.01$ & 20 \\
AgNPs $1000 \mu \mathrm{g} . \mathrm{L}^{-1}$ & $*$ & $*$ \\
\hline HA $2.5 \mathrm{mg} . \mathrm{L}^{-1}$ & $0.15 \pm 0.05$ & 12 \\
HA $10 \mathrm{mg} \cdot \mathrm{L}^{-1}$ & $0.08 \pm 0.01$ & 24 \\
\hline HA $50 \mathrm{mg} \cdot \mathrm{L}^{-1}$ & $*$ & $*$ \\
FA $2.5 \mathrm{mg} . \mathrm{L}^{-1}$ & $0.11 \pm 0.00$ & 12 \\
\hline FA $10 \mathrm{mg} . \mathrm{L}^{-1}$ & $0.08 \pm 0.00$ & 14 \\
FA $50 \mathrm{mg} . \mathrm{L}^{-1}$ & $0.10 \pm 0.00$ & 33
\end{tabular}

*No bacterial growth observed during the time of the experimentation.

Table 2. Combined effects of the different concentrations of the AgNPs, HA and FA on growth rate and on lag time of the Vibrio splendidus.

\begin{tabular}{|c|c|c|c|c|c|c|}
\hline & \multicolumn{6}{|c|}{ Growth rate $\left(\mathrm{h}^{-1}\right)$} \\
\hline & $\begin{array}{c}\mathrm{HA} \\
2.5 \mathrm{mg} \cdot \mathrm{L}^{-1}\end{array}$ & $\begin{array}{c}\text { HA } \\
10 \mathrm{mg} \cdot \mathrm{L}^{-1}\end{array}$ & $\begin{array}{c}\mathrm{HA} \\
50 \mathrm{mg} \cdot \mathrm{L}^{-1}\end{array}$ & $\begin{array}{c}\text { FA } \\
2.5 \mathrm{mg} . \mathrm{L}^{-1}\end{array}$ & $\begin{array}{c}\text { FA } \\
10 \mathrm{mg} \cdot \mathrm{L}^{-1}\end{array}$ & $\begin{array}{c}\text { FA } \\
50 \mathrm{mg} \cdot \mathrm{L}^{-1}\end{array}$ \\
\hline AgNPs $20 \mu g . L^{-1}$ & $0.10 \pm 0.01$ & $0.13 \pm 0.00$ & $0.11 \pm 0.00$ & $0.10 \pm 0.00$ & $0.12 \pm 0.00$ & $0.10 \pm 0.00$ \\
\hline AgNPs $100 \mu \mathrm{g} . \mathrm{L}^{-1}$ & $0.15 \pm 0.01$ & $0.22 \pm 0.00$ & $0.11 \pm 0.00$ & $0.13 \pm 0.00$ & $0.20 \pm 0.00$ & $0.11 \pm 0.00$ \\
\hline \multirow[t]{2}{*}{ AgNPs $1000 \mu \mathrm{g} . \mathrm{L}^{-1}$} & $0.08 \pm 0.00$ & $0.08 \pm 0.00$ & $0.11 \pm 0.00$ & $0.10 \pm 0.00$ & $0.11 \pm 0.00$ & $0.10 \pm 0.00$ \\
\hline & $\begin{array}{c}\text { HA } \\
2.5 \mathrm{mg.L}^{-1}\end{array}$ & $\begin{array}{c}\mathrm{HA} \\
10 \mathrm{mg} \cdot \mathrm{L}^{-1}\end{array}$ & $\begin{array}{c}\text { HA } \\
50 \mathrm{mg}^{-1}\end{array}$ & $\begin{array}{l}\text { FA time(h) } \\
2.5 \mathrm{mg} \cdot \mathrm{L}^{-1}\end{array}$ & $\begin{array}{c}\text { FA } \\
10 \mathrm{mg} \cdot \mathrm{L}^{-1}\end{array}$ & $\begin{array}{c}\text { FA } \\
50 \mathrm{mg}^{-1}{ }^{-1}\end{array}$ \\
\hline AgNPs $20 \mu g . L^{-1}$ & 24 & 26 & 33 & 24 & 25 & 33 \\
\hline AgNPs $100 \mu g . L^{-1}$ & 16 & 22 & 33 & 15 & 21 & 33 \\
\hline AgNPs $1000 \mu \mathrm{g} . \mathrm{L}^{-1}$ & 32 & 32 & 33 & 32 & 33 & 33 \\
\hline
\end{tabular}

expositions, the combination of the highest AgNPs and HA concentrations allowed bacterial growth after approximately $33 \mathrm{~h}$ (Table 2). These observations are consistent with $\mathrm{Su}$ et $a l .{ }^{28}$ who demonstrated that antibacterial effect of carbon nanotubes decreased in presence of $10 \mathrm{mg} . \mathrm{L}^{-1} \mathrm{HA}$ due to the adsorption of HA on the nanotube surface. The reduction of AgNPs toxicity at $1 \mathrm{mg} . \mathrm{L}^{-1}$ had also been observed on bacterial cells in biofilms by the addition of 10 mg. $L^{-1}$ HA. ${ }^{13}$ AgNPs are supposed to interact mainly with bacteria through their dissolution into $\mathrm{Ag}^{+}$ions. As a consequence, reduction of AgNPs toxicity could be due to a complexation of $\mathrm{HA}$ with $\mathrm{Ag}^{+}$or to a coating of AgNPs by HA that could prevent the release of $\mathrm{Ag}^{+}$ions. Liu and Hurt ${ }^{29}$ have demonstrated that NOM addition reduces the dissolution of AgNPs in water in a dose dependent manner. This could explain the reduction of AgNPs toxicity towards Vibrio splendidus cells observed at the highest concentrations used in our study. The effect of HA addition is higher than FA addition. As previously mentioned, HA and FA have a different chemical composition and could interfere differentially with AgNPs, and as a consequence with the liberation of $\mathrm{Ag}^{+}$ions.

\section{Conclusions}

In conclusion, our results demonstrated that the toxicological properties of AgNPs toward Vibrio splendidus cells are modified by the addition of HA and FA. As a consequence, risk assessment of nanomaterials in aquatic ecosystems requires to take into account the chemical (salts) composition of waters where AgNPs are dispersed but also the co-occurrence of NOM and their chemical composition (HA or FA) that could modify nanomaterialsxenobiotics toxicology.

\section{References}

1. Mcinroy L, Gibson M, Clark R, Cullen B. Are silver dressings effective against biofilm formation? Wound Repair Regen 2009; 17:A73.

2. Lem WK, Choudhury A, Lakhani AA, Kuyate P, Haw RJ, Lee SD, et al. Use of nanosilver in consumer products. Recent Pat Nanotechnol 2012;6:60-72. 
3. Dimkpa C0, Calder A, Gajjar P, Merugu S, Huang W, Britt DW, et al. Interaction of silver nanoparticles with an environmentally beneficial bacterium, Pseudomonas chlororaphis. J Hazard Mater 2011;188: 428-35.

4. US EPA. Emerging contaminants - nanomaterials fact sheet. EPA 505-F-509-011. Office of Solid Waste and Emergency Response; 2009.

5. Benn TM, Westerhoff P. Nanoparticle silver released into water from commercially available sock fabrics. Environ Sci Eng 2008;42:4133-9.

6. Dibrov P, Dzioba J, Gosink KK, Häse CC. Chemiosmotic mechanism of antimicrobial activity of $\mathrm{Ag}^{+}$in Vibrio cholerae. Antimicrob Agents Ch 2002;46:2668-70.

7. Holt KB, Bard AJ. Interaction of silver(I) ions with the respiratory chain of Escherichia coli: an electrochemical and scanning electrochemical microscopy study of the antimicrobial mechanism of micromolar $\mathrm{Ag}^{+}$. Biochemistry 2005; 44:13214-23.

8. Liau SY, Read DC, Pugh WJ, Furr JR, Russell AD. Interaction of silver nitrate with readily identifiable groups: relationship to the antibacterial action of silver ions. Lett Appl Microbiol 1997;25:279-83.

9. Xu X-HN, Brownlow WJ, Kyriacou SV, Wan Q, Viola JJ. Real-time probing of membrane transport in living microbial cells using single nanoparticle optics and living cell imaging. Biochemistry 2004;43:1040013.

10 Bradford A, Handy RD, Readman JW, Atfield A, Muhling M. Impact of silver nanoparticle contamination on the genetic diversity of natural bacterial assemblages in estuarine sediments. Environ Sci Eng 2009;43:4530-6.

11. Das P, Xenopoulos MA, Williams CJ, Hoque ME, Metcalfe CD. Effects of silver nanoparticles on bacterial activity in natural waters. Environ Toxicol Chem 2012;31:122-30.

12. Doiron K, Pelletier E, Lemarchand K.
Impact of polymer-coated silver nanoparticles on marine microbial communities: a microcosm study. Aquat Toxicol 2012;124125:22-7.

13. Wirth SM, Lowry GV, Tilton RD. Natural organic matter alters biofilm tolerance to silver nanoparticles and dissolved silver. Environ Sci Eng 2012;46:12687-96.

14. Miao A-J, Schwehr KA, Xu C, Zhang S-J, Luo Z, Quigg A, Santschi PH. The algal toxicity of silver engineered nanoparticles and detoxification by exopolymeric substances. Environ Pollut 2009;157:3034-41.

15. Navarro E, Piccapietra F, Wagner B, Marconi F, Kaegi R, Odzak N, et al. Toxicity of silver nanoparticles to Chlamydomonas reinhardtii. Environ Sci Eng 2008;42:895964 .

16. Fabrega J, Fawcett SR, Renshaw JC, Lead JR. Silver nanoparticle impact on bacterial growth: effect of $\mathrm{pH}$, concentration, and organic matter. Environ Sci Eng 2009;43:7285-90.

17. Tremblay L, Gagné J-P. Organic matter distribution and reactivity in the waters of a large estuarine system. Mar Chem 2009; 116:1-12.

18. McKnight D, Behmel P, Francko D, Gjessing E, Münster U, Petersen Jr R, et al. Group report how do organic acids interact with solutes, surfaces, and organisms? In: Perdue E, Gjessing E, eds. Organic acids in aquatic exosystems. John Wiley \& Sons Ltd: Dahlem Konferenzen; 1990. pp 223243.

19. Moura MN, Martín MJ, Burguillo FJ. A comparative study of the adsorption of humic acid, fulvic acid and phenol onto Bacillus subtilis and activated sludge. J Hazard Mater. 2007;149:42-8.

20. Stevenson F, Humus chemistry: genesis, composition, reactions. New York: Wiley; 1994.

21. Baalousha M, Nur Y, Römer I, Tejamaya M, Lead JR. Effect of monovalent and divalent cations, anions and fulvic acid on aggregation of citrate-coated silver nanoparticles. Sci Total Environ 2013;454-455:119-31.
22. Millour M, Pelletier E, Gagné JP. Interactions between silver nanoparticles and dissolved natural organic matter under estuarine conditions. In: $\mathrm{Xu} \mathrm{J}, \mathrm{Wu}$ JHe Y, eds. Functions of natural organic matter in changing environment. Amsterdam: Springer; 2013. pp 805-809.

23. Mateo DR, Siah A, Araya MT, Berthe FCJ, Johnson GR, Greenwood SJ. Differential in vivo response of soft-shell clam hemocytes against two strains of Vibrio splendidus: Changes in cell structure, numbers and adherence. J Invertebr Pathol 2009;102:506.

24. Berdjeb L, Pelletier É, Pellerin J, Gagné J$\mathrm{P}$, Lemarchand K. Contrasting responses of marine bacterial strains exposed to carboxylated single-walled carbon nanotubes. Aquat Toxicol 2013;144-145:230-41.

25. Nedwell DB, Rutter M. Influence of temperature on growth rate and competition between two psychrotolerant Antarctic bacteria: low temperature diminishes affinity for substrate uptake. Appl Environ Microbiol 1994;60:1984-92.

26. Visser S. Physiological action of humic substances on microbial cells. Soil Biol Biochem. 1985;17:457-62.

27. Kulikova NA, Perminova IV, Badun GA, Chernysheva MG, Koroleva OV, Tsvetkova EA. Estimation of uptake of humic substances from different sources by Escherichia coli cells under optimum and salt stress conditions by use of tritiumlabeled humic materials. Appl Environ Microbiol 2010;76:6223-30.

28. Su R, Jin Y, Liu Y, Tong $\mathrm{M}$, Kim $\mathrm{H}$. Bactericidal activity of Ag-doped multiwalled carbon nanotubes and the effects of extracellular polymeric substances and natural organic matter. Colloids Surf B 2013;104:133-9.

29. Liu J, Hurt RH. Ion release kinetics and particle persistence in aqueous nano-silver colloids. Environ Sci Eng 2010;44:216975 . 